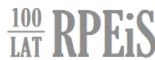

ŁUKASZ SKOCZYLAS*

\section{UPAMIĘTNIENIA FLORIANA ZNANIECKIEGO W PRZESTRZENI PUBLICZNEJ ${ }^{\text {*** }}$}

\section{WPROWADZENIE}

Celem niniejszego tekstu jest analiza upamiętnień Floriana Znanieckiego obecnych w przestrzeni publicznej. Zajmę się kwestią interpretacji i używania we współczesnej Polsce dziedzictwa Znanieckiego, a tym samym - tym, jak Znaniecki jest upamiętniany. Przez dziedzictwo Znanieckiego rozumiem tutaj bardzo szeroki ogół jego osiagnięć naukowych (metodologicznych, empirycznych i intelektualnych), osiagnięć organizacyjnych oraz samego Znanieckiego rozumianego jako postać historyczna, z jednej strony wpływająca na rzeczywistość $\mathrm{w}$ długim wymiarze czasowym, z drugiej - mająca pewne osobnicze cechy wyglądu, charakteru, życie prywatne, życie rodzinne itd. Upamiętnienie to zaś „kulturowa forma uobecniania minionych wydarzeń bądź osób w celu oddania im czci przez określoną grupę społeczna, która w ten sposób potwierdza własną tożsamość" mieć formę niematerialną lub materialną ${ }^{2}$ choć w obecnych społeczeństwach przemysłowych i postprzemysłowych nawet jeśli upamiętnienie jest niematerialne, to wiąże się z wieloma materialnymi nośnikami (np. opowieść zapisana jest w książkach i odtwarzana za pomoca rekwizytów teatralnych; procedura postępowania wiąże się z podręcznikiem lub rysunkiem instruktażowym; szkoła działa według spisanego statutu w określonym budynku itd.).

* Łukasz Skoczylas, Uniwersytet im. Adama Mickiewicza w Poznaniu, luke@amu.edu.pl,https://orcid.org/0000-0002-5946-2731

** Za pomoc w uzyskaniu informacji wykorzystanych w tym artykule dziękuję następujacym osobom i instytucjom: prof. UAM dr. hab. Janowi Włodarkowi, prof. UW dr. hab. Mikołajowi Pawlakowi, prof. dr. hab. Leszkowi Zasztowtowi, dr Aleksandrze Wójtowicz, Ewie Leszczyńskiej, Piotrowi Luczysowi, Biuru Filatelistyki Poczty Polskiej S.A., Biuru Geodezji i Katastru Urzędu Miasta Stołecznego Warszawy, Zarządowi Geodezji i Katastru Miejskiego GEOPOZ w Poznaniu.

1 Napiórkowski (2014): 509.

2 Skoczylas (2014): 25-34. 
Niezwykle istotną kwestia jest wspieranie tożsamości zbiorowości, której liderzy tworzą dane upamiętnienie, wprowadzając do pamięci społecznej tej zbiorowości nowe elementy lub nadając nowe znaczenie tym elementom, które już wcześniej były w niej obecne. W tym procesie dochodzić może także do wykorzystania komemoracji w celu wsparcia wybranych trendów społecznych lub politycznych obecnych $\mathrm{w}$ danej zbiorowości, prób rozszerzania lub zawężania jej identyfikacji, wsparcia interesów pewnych jej części lub nawet pojedynczych osób itd. Dlatego nowe upamiętnienia oraz sposób wykorzystania i zarządzania starymi stanowią tak ciekawy obiekt badań dla socjologów, którzy chcą poznać procesy zmiany w danej społeczności.

Główną sferą oddziaływania dziedzictwa Znanieckiego jest pole naukowe. Na podstawie badań bibliometrycznych ${ }^{3}$ stwierdzono, że jego wpływ mierzony liczbą cytowań w latach 1956-2016 był największy w następujących dyscyplinach: socjologia, psychologia, inne nauki społeczne, ekonomia, nauki edukacyjne, prawo, etnologia, demografia. Posługując się tą samą miara, zaobserwowano, że dokonania Znanieckiego cieszyły się największą popularnością wśród naukowców pochodzących z następujących krajów: USA, Anglia, Polska, Kanada, Australia, Niemcy, Hiszpania, Francja, Hiszpania, Włochy ${ }^{4}$. Kwestia ta jest już elementem pogłębionej refleksji, dlatego w niniejszym artykule spośród licznych odniesień do Znanieckiego ograniczę się do tych, które nie mają ściśle naukowego charakteru. Nie będę więc analizował jego wpływu na współczesne prądy badawcze lub metodologiczne, skupię się natomiast na wykorzystaniu jego dziedzictwa w bardziej nieoczywistych polach aktywności.

Większość upamiętnień, o których będę pisał, powstała kilkadziesiąt lat temu. Wedle mojej wiedzy osoby odpowiadające za te inicjatywy już nie żyją. Dane na temat ich motywacji i samego procesu upamiętnień próbowałem uzyskać w czasie konsultacji z kilkunastoma osobami - naukowcami, urzędnikami i lokalnymi aktywistami. Niestety nie byli oni w stanie udzielić mi innych informacji niż te, które zawarte są w oficjalnych dokumentach. Z tego powodu zdecydowałem się wykorzystać w moich badaniach metodę analizy dokumentów ${ }^{5}$.

Dokumentów poszukiwałem w materiałach archiwalnych udostępnianych przez następujące instytucje: Biuro Geodezji i Katastru m. st. Warszawy, Zarząd Geodezji i Katastru Miejskiego GEOPOZ w Poznaniu, Archiwum Zakładowe Poczty Polskiej, Archiwum Polskiej Akademii Nauk w Warszawie, Biblioteka Poznańskiego Towarzystwa Przyjaciół Nauk, Fundacja Naukowa im. Floriana Znanieckiego. Zdecydowanie najwięcej materiału przyniosła kwerenda w Archiwum Wydziału Socjologii Uniwersytetu im. Adama Mickiewicza w Poznaniu. Korzystałem także z materiałów z archiwum rodzinnego mgr. Stanisława Leszczyńskiego. W poszukiwaniach pomagali mi pracowni-

\footnotetext{
${ }^{3}$ Kubera, Skoczylas, Szerksznis (2017): 215-249.

${ }^{4}$ Kategoryzacja dyscyplin i krajów według Web of Science nie pokrywa się z politycznym podziałem na państwa. W obu przypadkach podaję 10 pierwszych pozycji. Zainteresowanych dalszymi miejscami odsyłam do publikacji cytowanej wyżej.

${ }^{5}$ Rapley (2013).
} 
cy tych instytucji oraz inne osoby wymienione w podziękowaniach. Do analizy wybierałem wszystkie dokumenty, których treść wiązała się z upamiętnieniami Floriana Znanieckiego, niezależnie od ich rodzaju. Udało mi się zgromadzić 49 dokumentów o bardzo różnej zawartości (od krótkich pism wymienianych pomiędzy jednostkami uniwersyteckimi po wielostronicowe protokoły zebrań). Dokumenty analizowałem jakościowo, biorąc pod uwagę przede wszystkim ich treść oraz kontekst instytucjonalny (kto był autorem dokumentu, kto odbiorca, jakie instytucje reprezentowali). Pomijałem przy tym ich formę. Ze względu na oficjalny charakter analizowanych dokumentów użyłem ich przede wszystkim w celu stworzenia spójnego obrazu faktograficznego dotyczącego upamiętnień Znanieckiego. W swoich rozważaniach wziąłem także pod uwagę treść tablic pamiątkowych znajdujących się w przestrzeni publicznej Poznania i Świątnik.

Prezentację swoich dociekań zacznę od skrótowego przedstawienia sylwetki Znanieckiego. Następnie przejdę do przeglądu komemoracji Znanieckiego: wymienię je, wyróżniając główne sposoby wykorzystania jego dziedzictwa i cele, jakie temu wykorzystaniu przyświecaja. Pod uwagę wezmę upamiętnienia materialne obecne w przestrzeni publicznej (nazwa ulicy, tablica pamiątkowa). Wreszcie postaram się podsumować swoje rozważania, wskazując, w jaki sposób postać Znanieckiego wykorzystywano do tworzenia treści pamięciowych oraz wspierania określonych narracji o przeszłości.

\section{FLORIAN ZNANIECKI}

Najwybitniejsze dokonania Floriana Znanieckiego (1882-1958) można opisać, odnosząc się do trzech głównych sfer jego działalności: organizacyjnej, metodologicznej i empirycznej.

Pierwsza z nich obejmuje szereg działań zmierzających do instytucjonalizacji polskiej socjologii. Znaniecki realizował ten cel dwutorowo: tworząc i rozwijając akademicką socjologię w Poznaniu oraz animując życie naukowe osób zainteresowanych socjologia. Znaniecki w marcu 1920 r., po powrocie ze Stanów Zjednoczonych, obją na Uniwersytecie Poznańskim Katedrę Filozofii III, która wkrótce - dzięki jego zabiegom - przekształcona została w Katedrę Socjologii i Filozofii Kultury, rozpoczynając instytucjonalizację akademickiej socjologii w Polsce. Znaniecki założył seminarium socjologiczne, a w roku akademickim 1927/1928 - otworzył w Poznaniu studia socjologiczne. Ponadto podjął próby dołączenia do już istniejącego czasopisma „Ruch Prawniczy i Ekonomiczny” działu socjologicznego, co udało się w 1925 r., od kiedy publikowane jest ono jako „Ruch Prawniczy, Ekonomiczny i Socjologiczny”. W 1930 r. Znaniecki rozpoczą wydawanie czasopisma poświęconego tylko socjologii - „Przeglądu Socjologicznego”. Jego formalnym wydawcą był założony przezeń w 1921 r. Instytut Socjologiczny, mający skupiać osoby prowadzące badania w tej dyscyplinie nauki. Instytut ten w 1928 r. został przemianowany na Polski Instytut Socjologiczny, uzyskując wsparcie publiczne ze strony władz centralnych. Jego działalność umożliwiła organizację w 1931 r. w Poznaniu pierwszego Zjazdu Socjologów 
Polskich ${ }^{6}$. Pracę organizacyjna Znaniecki kontynuował także w czasie swojego powojennego pobytu w Stanach Zjednoczonych - w latach 1954-1955 był przewodniczącym Amerykańskiego Towarzystwa Socjologicznego ${ }^{7}$.

Metodologiczna sfera działalności Znanieckiego to przede wszystkim stworzenie metody autobiograficznej w socjologii. Zakłada ona dokładne badanie historii życia jednostek w celu możliwe pełnego poznania wartości, jakie przypisują one różnym rzeczom. Dzięki temu możliwe staje się zbadanie procesu społecznego wyznaczania znaczeń. Materiałami badawczymi w metodzie autobiograficznej są materiały autobiograficzne, takie jak np. pamiętniki, dzienniki lub listy. Metoda ta, wpisująca się w szerszy nurt socjologii humanistycznej, po dziś dzień jest często w socjologii wykorzystywana, szczególnie w sferach wymagających głębokiego zrozumienia motywacji działań podejmowanych przez uczestników różnych przemian społecznych. Zdaniem Znanieckiego wszystkie zjawiska społeczne zależą od czynności podejmowanych przez ludzi, należy więc oceniać je właśnie przez ten pryzmat. Nazwany on został przez Znanieckiego wspótczynnikiem humanistycznym. Ponadto Znaniecki był autorem szeregu koncepcji teoretycznych: zakładał m.in., że socjologia jest nauką badająca kulturę (kulturalizm) oraz że wyróżnić można cztery typy osobowości ${ }^{8}$. Różnorodność dokonań Znanieckiego na polu teoretycznym sprawia, że część z jego dzieł wciąż stanowi fundament rozważań na gruncie pozasocjologicznej refleksji społecznej, np. pedagogicznej i politologicznej.

$\mathrm{W}$ zakresie badawczo-empirycznym Znaniecki również jest pionierem współczesnej socjologii w wymiarze światowym. Jego badania „Miasto w świadomości jego obywateli” ${ }^{\prime \prime}$ sa jednym z pierwszych opracowań badawczych z zakresu socjologii miasta, natomiast - wykonane wraz z Williamem I. Thomasem - badania nad integracją Polaków w Stanach Zjednoczonych przez lata wyznaczały kierunki badań migracyjnych ${ }^{10}$.

\section{UPAMIECTNIENIA ZNANIECKIEGO W PRZESTRZENI PUBLICZNEJ}

Najstarszym materialnym upamiętnieniem Floriana Znanieckiego w postaci innej niż książkowa jest tablica pamiątkowa z 1972 r. ${ }^{11}$, wmurowana w jedną ze ścian bloku C przy głównych salach wykładowych Collegium Novum Uniwersytetu im. Adama Mickiewicza w Poznaniu. Społeczność UAM, faktycznego i duchowego następcy Uniwersytetu Poznańskiego, nie zapomniała o założycielu polskiej socjologii instytucjonalnej. W roku, na który przypadała 90. rocznica jego urodzin, w jednym z ówcześnie najnowszych i naj-

\footnotetext{
${ }^{6}$ Ziółkowski (1973): 327-348.

${ }^{7}$ Rhoades (1981): 79.

${ }^{8}$ Dulczewski (2000): 43-130.

${ }^{9}$ Znaniecki (1931).

10 Thomas, Znaniecki (1918).

${ }^{11}$ Dulczewski (1984): 381.
} 
bardziej nowoczesnych obiektów akademickich Poznania odsłonięto medalion z rzeźbionym profilem Znanieckiego, pod którym umieszczono tablicę pamiątkowa. Znalazł się na niej następujacy napis wersalikami: „Florian Znaniecki / 15.I.1882 - 23.III.1958 / profesor Uniwersytetu Poznańskiego / 1920-1939 / światowej sławy socjolog / twórca polskiej socjologii uniwersyteckiej / założyciel Polskiego Instytutu Socjologicznego / oraz czasopisma „Przegląd Socjologiczny" / wychowawca pokolenia socjologów polskich”. Treść napisu skrócono niemal o połowę w porównaniu z pierwotnym pomysłem ${ }^{12}$. Niestety w archiwach nie zachował się oryginalny projektu napisu przed skróceniem.

Na tablicy wyróżniono przede wszystkim działalność organizacyjną Znanieckiego, jego związek z Uniwersytetem Poznańskim oraz działalność dydaktyczno-formacyjną. Nie wspomniano o dokonaniach naukowych, co jest o tyle zrozumiałe, że z powodów ideowo-politycznych były one mocno krytykowane w pierwszych dziesięcioleciach PRL. Socjologię Znanieckiego stawiano często w jednym rzędzie z tzw. socjologią burżuazyjną i uznawano za szkodliwą dla nauki ${ }^{13}$. Krytyka ta wychodziła przede wszystkim od kół akademickich szczególnie bliskich władzy, wpływała jednak jednocześnie na ogólny sposób odbioru Znanieckiego. Po 1970 r. ataki na poszczególne nurty metodologiczne i teoretyczne oraz siłowe promowanie marksizmu znacznie osłabły ${ }^{14}$, co być może także przełożyło się na atmosferę odwilży i możliwość upamiętnienia Znanieckiego. Przywracanie socjologii Znanieckiego do głównego nurtu zaczęło się jednak wcześniej, pod koniec lat sześćdziesiątych XX w., przez - raczej fasadowa - reinterpretację jego dorobku, umożliwiająca dopasowanie jej do myśli społecznej głównego nurtu politycznego. Oddają to artykuły popularyzatorskie, drukowane w 10. rocznicę śmierci Znanieckiego ${ }^{15}$. Dziedzictwo twórcy współczynnika humanistycznego stało się także jednym z głównych wątków drugiego powojennego Zjazdu Socjologicznego, który odbył się w 1969 r. ${ }^{16}$

Odsłonięcia tablicy dokonano 15 grudnia 1972 r., w pierwszym dniu konferencji „Florian Znaniecki i jego rola w socjologii”, zorganizowanej przez Instytut Socjologii UAM. Równocześnie imię Znanieckiego nadano jednej z większych sal w Collegium Novum. W czasie uroczystości oraz na całej konferencji obecna była córka Znanieckiego, Helena Znaniecka-Lopata, wykładowca socjologii na Loyola University w Stanach Zjednoczonych. W konferencji brało także udział z referatami piętnastu innych socjologów z pięciu ośrodków akademickich (Warszawa, Łódź, Kraków, Katowice, Poznań). Kilku reprezentantów innych ośrodków (Lublin, Wrocław, Szczecin, Zielona Góra) przyjechało, aby ich wysłuchać. Na czas konferencji zawieszono zajęcia uniwersyteckie, więc obradom przysłuchiwali się także studenci. Opisywaną konferencję oraz

12 List dyrektora Instytutu Socjologii UAM prof. Andrzeja Kwileckiego do rektora UAM prof. Czesława Łuczaka, 12.07.1972; Archiwum Wydziału Socjologii UAM; List dyrektora Instytutu Socjologii UAM prof. Andrzeja Kwileckiego do dyrektora administracyjnego UAM mgr. Jana Drzewińskiego, 12.07.1972; Archiwum Wydziału Socjologii UAM.

13 Bielecka-Prus (2009): 79.

14 Bielecka-Prus (2009): 89.

15 Jakubczak (1968a); Jakubczak (1968b).

16 Nowak (2010): 42-43. 
odsłonięcie pierwszej tablicy pamiątkowej poświęconej Znanieckiemu można potraktować jako szczególnie ważne. Z jednej strony wyznaczyły one ramy organizacyjne i formalne dla kolejnych upamiętnień, z drugiej - wydarzenia te miały miejsce zaledwie cztery lata po wznowieniu w Poznaniu studiów socjologicznych, zamkniętych w 1952 r. z powodów politycznych ${ }^{17}$. Współtworzyły one więc tożsamość zawodową studentów i nowych pracowników zatrudnionych na UAM w celu realizacji zadań dydaktycznych, budowały symboliczną więź z okresem międzywojennym i z międzynarodowym środowiskiem socjologów.

Na kolejne upamiętnienia przyszło czekać niecałe 10 lat. W latach 19791980 powstawał cykl głów Wybitni uczeni polscy ${ }^{18}$ znanej rzeźbiarki Zofii Wolskiej. Wśród upamiętnionych postaci, poza Znanieckim, znaleźli się: Oskar Lange (ekonomista), Jan Dembowski (biolog), Wojciech Rubinowicz (fizyk), Wojciech Świętosławski (chemik), Tadeusz Hobler (chemik), Eugeniusz Pijanowski (chemik), Ludwik Hirszfeld (immunolog). Wolska znana jest z dwóch cykli tego typu rzeźb. Wcześniejszy, Ludzie regionu kieleckiego, stanowił hołd autorki dla wybitnych postaci rodzinnych stron ${ }^{19} \mathrm{i}$ grupował zasłużone osoby różnych profesji, żyjące na przestrzeni wielu lat. Te dwa zespoły dzieł porównane zostały przez Jerzego Madeyskiego w następujący sposób: „Drugi wielki cykl poświęcony jest wybitnym uczonym polskim. Trudniejszy od poprzedniego z racji nieuniknionego podobieństwa charakterów, piętna, jakie wyciskają na twarzy podobne cechy osobowości i właściwe uczonym skupienie. Ludzie regionu kieleckiego reprezentowali różne zawody i różne tym samym temperamenty. Uczeni całego świata należą do tego samego gatunku ludzi parających się jednym problemem i skoncentrowanych na nim. Lecz Wolska była już dojrzałą artystką. W Uczonych operuje oszczędną i spokojniejsza, bo mniej dynamiczną formą. Modelunek jest płytki, bryła bardziej zwarta i przez to bardziej monumentalna. A jedna z cech monumentalizmu jest dostojeństwo Wiedzy i parającego się nią człowieka. Również w tym przypadku forma odpowiada treści przesłania i jest z nią jednaka" ${ }^{20}$. Głowa Znanieckiego eksponowana jest obecnie w holu na pierwszym piętrze Pałacu Staszica w Warszawie, przy wejściu do Sali Lustrzanej21. Obok znajdują się rzeźby upamiętniające Świętosławskiego, Rubinowicza, Pijanowskiego i Hoblera.

Kolejne upamiętnienie ustanowiono w Warszawie zaledwie kilka lat później. Uchwałą nr 35 Rady Narodowej Miasta Stołecznego Warszawy imieniem Znanieckiego nazwana została ulica na nowym osiedlu Gocław w dzielnicy Praga Południe. Uchwałę podjęto 22 marca $1982 \mathrm{r}^{22} \mathrm{~W}$ ramach tych samych działań nadano nowa nazwę trzem ulicom i placowi w tej samej dzielnicy. Wszystkie nowe nazwy upamiętniały osoby zasłużone dla nauki - poza Znanieckim uhonorowano także historyka Tadeusza Manteuffla oraz filozofów: Władysława Tatarkiewicza i Tadeusza Kotarbińskiego. Ulica Znanieckiego

\footnotetext{
17 Tyszka (1975).

18 Wolska (2000): 206.

19 Madeyski (2000): 47.

20 Madeyski (2000): 47-48.

21 Wójtowicz (2017): 87.

22 Dz. Urz. Rady Narodowej m. st. Warszawy 1982, nr 4, poz. 17.
} 
nie miała wcześniej nazwy. Jest to ulica zabudowana wolno stojącymi budynkami mieszkalnymi z lat osiemdziesiątych XX w. i późniejszych, dochodzi do niej mnóstwo innych dróg, często ślepych, które także na mapach oznaczone sa jako ulica Znanieckiego. Według oficjalnej ewidencji obecnie łączy ona ulicę Władysława Umińskiego (pisarz science fiction) oraz Kanał Gocławski i ma bardzo niejednorodny przebieg: od Umińskiego południowo-wschodni, potem północno-wschodni, północno-zachodni, znów północno-wschodni i w końcu wzdłuż kanału znów południowo-wschodni ${ }^{23}$. Uliczki dojazdowe, o których wspominałem wyżej, łączą się także z ulicą Tadeusza Rechniewskiego (działacz oświatowy), Kanałem Nowa Ulga, a poprzez trakt pieszo-rowerowy nad tym kanałem i pod aleją Bolesława Wieniawy-Długoszewskiego (wojskowy) - także z ulicą Kosmatki (roślina) na Nowym Wawrze. Część budynków posiadających adres na ulicy Znanieckiego sasiaduje także z ulica Tadeusza Bora-Komorowskiego (generał). Jak widać, choć w uchwale dotyczącej ulic na Gocławiu Znanieckiemu towarzyszyli inni wybitni naukowcy, nazewnictwo okolicznych ulic nie podporządkowuje się jasnemu schematowi. Biogram Znanieckiego udostępniany przez warszawski urząd miasta, choć krótki, wymienia bardzo wiele sfer jego działalności (badawcza, organizacyjna, metodologiczno-teoretyczna), pobyty w Stanach Zjednoczonych, a nawet podaje jego najważniejsza dzieła. Znaniecki jest w nim przedstawiony jako filozof i socjolog, który zajmował się także psychologią i socjologią wychowania ${ }^{24}$. Skomplikowany układ warszawskiej ulicy Floriana Znanieckiego jasno pokazuje, że nie jest to ulica reprezentacyjna, nawet w wymiarze dzielnicowym. Okoliczne toponimy nie sa powiązane z socjologią lub nauka, najprawdopodobniej więc nadanie właśnie tej ulicy imienia socjologa było przypadkiem. Można domniemywać, że uhonorowanie Znanieckiego w roku 1982 związane było po prostu z obchodzona w tym roku 100. rocznica jego urodzin - jego imieniem nazwano ulicę, która akurat wtedy została wytyczona.

Podobny zamysł uczczenia urodzin Znanieckiego pojawił się w Poznaniu. Swoje wnioski do władz miejskich ws. nadania imienia uczonego jednej z ulic wysłały: Poznańskie Towarzystwo Przyjaciół Nauk (w 1979) oraz Instytut Socjologii UAM ${ }^{25}$ i dziennik „Głos Wielkopolski” (oba w 1982). Wniosek IS UAM związany był z międzynarodową konferencją „The Florian Znaniecki Symposium”, która odbyła się w Poznaniu 3-4 grudnia 1982 r. Imię socjologa nadano dopiero po kilku latach południowemu fragmentowi ulicy Władysława Biegańskiego (lekarza) na poznańskim Piątkowie. Zmian dokonano 29 listopada 1984 r. uchwałą Miejskiej Rady Narodowej nr IV/19/84. Były one zapewne częścią szerszego planu uporządkowania urbanistycznego tych terenów. Załącznik do uchwały, w którym wymieniono nowe nazwy ulic, zmiany przebiegu lub likwidację innych, liczy aż 10 stron i w dużej części dotyczy północnej części miasta. Wraz ze Znanieckim patronami ulic uczyniono: Wacława Gieburowskiego (kompozytor), Stanisława Wachowiaka (polityk), Henryka Łowmiań-

\footnotetext{
${ }^{23}$ Nazewnictwo (2020).

${ }^{24}$ Znaniecki (2020).

25 Dulczewski (1984): 381.
} 
skiego (historyk), Kazimierza Tymienieckiego (historyk), Jana Sokołowskiego (zoolog), Mikołaja Dobrzyckiego (powstaniec), Kazimierza Mielęckiego (powstaniec), Karola Szymanowskiego (kompozytor), Karola Kurpińskiego (kompozytor), Mikołaja Rudnickiego (językoznawca), Helenę Modrzejewską (aktorka), Stefana Jaracza (aktor), Ludwika Solskiego (reżyser), Juliusza Osterwę (aktor), Franciszka Rylla (reżyser), Wincentego Rapackiego (aktor), Nunę i Bolesława Szczurkiewiczów (reżyserzy). Choć lista ta może sprawiać wrażenie mało usystematyzowanej, jeśli weźmiemy pod uwagę tylko drogi na Piątkowie, widzimy dość wyraźnie, że ich nazwy tematycznie ograniczaja się do naukowców, kompozytorów oraz polityków. Dodatkowo sama ulica Znanieckiego krzyżuje się z kilkoma innymi „naukowymi” ulicami. Ten bardzo ogólny schemat, w który wpisuje się istniejąca już wcześniej ulica Biegańskiego, do dziś pozostaje aktualny. Warto zauważyć, że choć decyzję poznański magistrat podją pod koniec 1984 r., ulica Znanieckiego na planach miasta pojawiła się dopiero w roku $1987^{26}$. Od pierwszego zgłoszenia pomysłu przez PTPN do jego realizacji minęło osiem lat. W przeciwieństwie do Warszawy, poznańska ulica Znanieckiego otrzymała swojego patrona w sposób nieprzypadkowy. Cała najbliższa okolica związana jest toponimicznie z zasłużonymi naukowcami, co ułatwia interpretację dokonań Znanieckiego przez osobę nieznająca jego osiagnięć (np. przechodnia widzącego nazwę ulicy). Warto jednak zauważyć, że także poznańska ulica Znanieckiego nie jest traktem reprezentacyjnym, nawet w wymiarze dzielnicowym.

Ciekawe jest uzasadnienie uhonorowania Znanieckiego dołączone do uchwały. Znaniecki został tam przedstawiony przede wszystkim jako naukowiec zwiąany z Wielkopolska oraz Stanami Zjednoczonymi (wspomniana została jego praca w Illinois oraz prezesura w Amerykańskim Towarzystwie Socjologicznym). Wspomniano także o działalności organizacyjnej (utworzenie Instytutu Socjologicznego) i konkursie pamiętnikarskim skierowanym do ludzi pracy. Podkreślono światowe znaczenie dorobku polskiego socjologa.

Ulica Znanieckiego w Poznaniu biegnie na osi północ-południe. Od południa wychodzi prostopadle z ulicy Kazimierza Tymienieckiego, następnie wpada w nią od wschodu ulica Konstantego Troczyńskiego (literaturoznawca). Dalej ulica Znanieckiego przecina osiedle Bolesława Chrobrego (król Polski), docierając w końcu do ulicy Wachowiaka. Od Tymienieckiego do Chrobrego, po zachodniej stronie ulicy zdecydowanie dominuje zabudowa jednorodzinna i bliźniacza, po wschodniej zaś występuje ona mniej więcej do połowy długości ulicy. Dalej znajduje się duży budynek wielorodzinny z 2000 r. Na terenie osiedla Chrobrego ulica Znanieckiego staje się traktem pieszym, a znajdujące się przy niej bloki z wielkiej płyty maja adres osiedlowy. W 2019 r. jeden z dużych deweloperów ukończył w okolicy budowę kilku dużych budynków mieszkalnych. W ramach tej inwestycji od strony ulicy Znanieckiego wybudowano także jeden mniejszy budynek, w którym znajdowały się cztery mieszkania. Obiekt nazwano „Willa Znanieckiego” i pod tą nazwą reklamowano w Internecie oraz na billboardach. Po rozpoczęciu wprowadzania Systemu Identyfi-

${ }^{26}$ Poznań: Plan miasta (1985); Poznań: Plan miasta (1987). 
kacji Miejskiej w roku 2004 wymianie uległy tablice z nazwami większości ulic w Poznania, a jedna ze starych tabliczek z ulicy Znanieckiego zdobi dziśs korytarz Wydziału Socjologii UAM na kampusie Ogrody.

10 czerwca 2000 r. ${ }^{27}$ na ścianie kościoła w miejscowości Świątniki (powiat włocławski, gmina Lubraniec) odsłonięto tablice poświęconą Znanieckiemu ${ }^{28}$. Napis wersalikami na tablicy brzmi: „Florian Witold Znaniecki / ur. 15.I.1882 we wsi Świątniki k. Włocławka, Polska / zm. 23.III.1958 w Urbana-Champaign k. Chicago, USA / uczony światowej sławy - syn Ziemi Kujawskiej / filozof - humanista klasyk socjologii / wybitny przedstawiciel socjologii amerykańskiej / twórca polskiej socjologii akademickiej / wychowawca całych pokoleń polskich socjologów / Cześć Jego pamięci! / Fundator - Zachodniopomorska Szkoła Biznesu / Instytut Kształcenia Manadżerów / we Włocławku / czerwiec 2000”. Uroczystości odbywały się w trzech miejscach: najpierw we Włocławku (trzy prelekcje na temat działalności Znanieckiego oraz występ chóru Canto z miejscowego Zespołu Szkół Muzycznych), następnie w Świątnikach (odsłonięcie tablicy) i w końcu w Lubrańcu (sesja Rady Miasta i Gminy oraz wykład o Znanieckim). Poza wspomnianymi wyżej instytucjami w przedsięwzięciu pomagały także Lasy Państwowe. Inicjatorem tego upamiętnienia był Zygmunt Dulczewski ${ }^{29}$, od lat współpracujący w badaniu życiorysu Znanieckiego z mgr. Stanisławem Leszczyńskim, nauczycielem, poetą i rzeźbiarzem z gminy Lubraniec.

26 kwietnia 2010 r. decyzją Senatu UAM jeden z budynków na kampusie Ogrody UAM otrzymał nazwę Collegium Znanieckiego. 28 października tego roku przed głównym wejściem odsłonięto tablicę upamiętniającą wraz z profilem Znanieckiego wyrzeźbionym na tle budynku Auli Uniwersyteckiej. Aula wchodzi w skład większego kompleksu Collegium Minus, w którym w latach 1920-1933 znajdowała się siedziba kierowanych przez Znanieckiego: seminarium socjologicznego oraz Katedry Socjologii i Filozofii Kultury. Na tablicy znalazły się następujące słowa zapisane wersalikami: „Florian Znaniecki / 1882-1958 / światowej sławy uczony, socjolog, filozof / teoretyk kultury i wychowania, psycholog społeczny, / założyciel pierwszego w Polsce / Instytutu Socjologicznego (Poznań, 1920), / profesor Uniwersytetu Poznańskiego (1920-1939), / Columbia University oraz University of Illinois / at Urbana-Champaign". Inskrypcja skupia się przede wszystkim na międzynarodowych powiązaniach upamiętnianego oraz na interdyscyplinarności jego pracy. Jest to zrozumiałe, biorąc pod uwagę, że 1) tablicę odsłonięto w czasie wzmożonego nacisku instytucjonalnego na umiędzynarodowienie polskiej nauki; 2) w Collegium Znanieckiego odbywały się zajęcia dla studentów licznych kierunków dwóch uniwersyteckich Wydziałów (Nauk Społecznych i Nauk Edukacyjnych), więc wskazanie bogactwa dorobku Znanieckiego otwierało upamiętnienie na studentów i przedstawicieli innych niż socjologia nauk społecznych i humanistycznych. W uroczystości odsłonięcia tablicy brali udział m.in. rektor UAM

\footnotetext{
27 Znaniecki (2000).

28 Dulczewski (1999): 17.

${ }^{29}$ Kwilecki (2007): 86-87.
} 
Bronisław Marciniak oraz wnuk Znanieckiego - Michał Znaniecki, reżyser operowy ${ }^{30}$.

Kolejna tablica pamiątkowa została odsłonięta w Poznaniu 19 października 2019 r. na budynku publicznego Przedszkola nr 83 „Zuch”, przy ulicy Kasztaleńskiej 19. W tym miejscu Znaniecki mieszkał wraz z rodzina w latach 1937-1939 ${ }^{31}$. Odsłonięcie tablicy było zwieńczeniem projektu badawczego przeprowadzonego na osiedlu Abisynia, na którym znajduje się przedszkole, a inspirowanego klasycznymi badaniami Znanieckiego „Miasto w świadomości jego obywateli” ${ }^{2}$. Jednocześnie świętowano 30-lecie Fundacji Naukowej im. Floriana Znanieckiego. Tablicę odsłonili: prezes Stowarzyszenia Mieszkańców „Abisynia” Anna Sasiak-Patkowska oraz dyrektor Fundacji Jacek Kubera; towarzyszył im Michał Znaniecki. W ramach uroczystości odbył się wykład biograficzny autorstwa Adama Czecha, przedstawienie wyników badań przeprowadzonych na Abisynii oraz wystawa prac artystycznych poświęconych Znanieckiemu wykonanych przez podopiecznych przedszkola. $\mathrm{Na}$ tablicy znajduje się wizerunek Znanieckiego oraz napis wersalikami: „W tym domu w latach 1937-1939 mieszkał i tworzył / Florian Znaniecki / światowej sławy socjolog, filozof kultury, humanista, / ojciec instytucjonalnej polskiej socjologii”.

Najnowsze upamiętnienie w przestrzeni publicznej jest o tyle ciekawe, że grono jego inicjatorów wykracza poza środowisko naukowe. Pomysł wmurowania tablicy wiąże się z wydaną dwa lata wcześniej książką Aleksandra Przybylskiego ${ }^{33}$, dotycząca historii osiedla Abisynia. Zostali tam wymienieni i krótko opisani jego zasłużeni mieszkańcy, w tym m.in. Florian Znaniecki. Stąd zainteresowanie stowarzyszenia zrzeszającego mieszkańców osiedla i ich działania mające na celu stworzenie upamiętnienia.

\section{PODSUMOWANIE}

Upamiętnienia zaspokajaja potrzeby tożsamościowe komemorujących, wpływając na pamięć społeczną zbiorowości, z której wywodzą się ich inicjatorzy. Kształt upamiętnień, oficjalne uzasadnienia ich powstania oraz sposoby zarządzania nimi pozwalają kreować wyobrażenie o przeszłości w pożądany sposób. Komemoracje sa jednymi z głównych obiektów działań liderów pamięci, którzy tworzą narracje o przeszłości, starając się przekonać do niej osoby niezainteresowane historią. Często upamiętnienia stanowią materialny dowód istnienia wspólnoty, do którego odwołać mogą się osoby nieposiadające na jej temat dużej wiedzy. Dlatego też analizując je, należy zwrócić uwagę na cele przyświecające ich powstaniu inne niż chęć uhonorowania zasłużonej osoby.

\footnotetext{
${ }^{30}$ Collegium (2010).

31 Przybylski (2017).

32 Znaniecki (1931):

${ }^{33}$ Przybylski (2017).
} 
Jak wskazałem wyżej, Znanieckiego upamiętniono w trzech miejscowościach w Polsce: w Warszawie (ulica i głowa), Poznaniu (trzy tablice z płaskorzeźbami twarzy, ulica, nazwa budynku oraz sali wykładowej) i Świątnikach (tablica). Liczebnie przeważają upamiętnienia w Poznaniu, co - ze względu na działalność Znanieckiego - wydaje się zrozumiałe. Wszystkie upamiętnienia koncentrują się na jego naukowych osiagnięciach, akcentując jednak nieco inne ich elementy lub interpretacje.

Tabela

Formy upamiętnienia Floriana Znanieckiego w przestrzeni publicznej

\begin{tabular}{|c|c|c|c|}
\hline $\begin{array}{c}\text { Rok } \\
\text { powstania }\end{array}$ & Miejscowość & $\begin{array}{c}\text { Forma } \\
\text { upamiętnienia }\end{array}$ & $\begin{array}{c}\text { Uzasadnienie } \\
\text { powstania }\end{array}$ \\
\hline 1972 & Poznań & $\begin{array}{l}\text { Tablica w Colle- } \\
\text { gium Novum UAM, } \\
\text { nadanie patronatu } \\
\text { sali dydaktycznej }\end{array}$ & $\begin{array}{l}\text { Działalność organizacyjna, działalność } \\
\text { edukacyjna, międzynarodowe uznanie, } \\
\text { związek z Poznaniem }\end{array}$ \\
\hline 1980 & Warszawa & $\begin{array}{l}\text { Głowa w Pałacu } \\
\text { Staszica }\end{array}$ & b.d. \\
\hline 1982 & Warszawa & Ulica na Gocławiu & $\begin{array}{l}\text { Działalność organizacyjna, międzynaro- } \\
\text { dowe uznanie, } \\
\text { związek z Poznaniem, } \\
\text { pionierstwo naukowe, } \\
\text { dokonania metodologiczne, } \\
\text { rola w nauce, } \\
\text { różnorodność dokonań naukowych }\end{array}$ \\
\hline 1984 & Poznań & Ulica na Piątkowie & $\begin{array}{l}\text { Działalność organizacyjna, międzynaro- } \\
\text { dowe uznanie, } \\
\text { związek z Poznaniem i Wielkopolska, } \\
\text { pionierstwo naukowe, } \\
\text { refleksja nad ludźmi pracy, } \\
\text { rola w nauce }\end{array}$ \\
\hline 2000 & Świątniki & Tablica na kościele & $\begin{array}{l}\text { Działalność organizacyjna, } \\
\text { działalność edukacyjna, międzynarodo- } \\
\text { we uznanie, } \\
\text { związek z Kujawami, } \\
\text { pionierstwo naukowe, } \\
\text { rola w nauce, } \\
\text { różnorodność dokonań naukowych }\end{array}$ \\
\hline 2010 & Poznań & $\begin{array}{l}\text { Tablica na Colle- } \\
\text { gium im. Floriana } \\
\text { Znanieckiego UAM, } \\
\text { nadanie patronatu } \\
\text { budynkowi dydak- } \\
\text { tycznemu }\end{array}$ & $\begin{array}{l}\text { Działalność organizacyjna, } \\
\text { międzynarodowe uznanie, } \\
\text { związek z Poznaniem, } \\
\text { pionierstwo naukowe, } \\
\text { różnorodność dokonań naukowych }\end{array}$ \\
\hline 2019 & Poznań & $\begin{array}{l}\text { Tablica na Przed- } \\
\text { szkolu nr } 83 \text { „Zuch” }\end{array}$ & $\begin{array}{l}\text { Działalność organizacyjna, } \\
\text { międzynarodowe uznanie, } \\
\text { pionierstwo naukowe, } \\
\text { różnorodność dokonań naukowych }\end{array}$ \\
\hline
\end{tabular}

Źródło: opracowanie własne. 
Powyższa tabela umożliwia wskazanie podstawowych uzasadnień stosowanych w upamiętnieniach Znanieckiego:

- działalność organizacyjna,

- działalność edukacyjna (w tym wychowawcza),

- międzynarodowe uznanie (zwykle określane mianem „światowego”),

- związek z Poznaniem lub Wielkopolską albo Kujawami,

- dokonania metodologiczne,

- rola w nauce (przedstawiciel jednego z nurtów w socjologii, mistrz myśli socjologicznej, wybitny przedstawiciel socjologii),

- pionierstwo naukowe,

- różnorodność dokonań naukowych (socjolog, filozof, filozof kultury, humanista, psycholog społeczny, teoretyk kultury i wychowania, socjolog wychowania).

Poszczególne uzasadnienia, choć powtarzające się przy okazji ustanawiania kilku upamiętnień, różnicują je między sobą. W zależności od miejsca oraz docelowej wspólnoty pamięci uwypuklane są wybrane cechy lub aspekty działalności Znanieckiego.

Podkreślanie wagi osiagnięć naukowych Znanieckiego i przypominanie jego dziedzictwa służy poznańskiemu ośrodkowi socjologicznemu jako jeden z najtrwalszych elementów tożsamościowych. Uwypukla pionierskość Poznania i jego odrębność jako pierwszej akademickiej instytucji socjologicznej (1920, Katedra Socjologii i Filozofii Kultury; w tym samym roku podobna katedrę założono w Warszawie); miejsca wydania pierwszych w Polsce czasopism socjologicznych (,Ruch Prawniczy, Ekonomiczny i Socjologiczny” od 1925; przedwojenny „Przegląd Socjologiczny” od 1930) ${ }^{34}$, miejsce pierwszego Zjazdu Socjologów $(1931)^{35}$ i wreszcie miejsce powstania pierwszej niezależnej instytucji socjologicznej (Instytut Socjologiczny od 1921, Polski Instytut Socjologiczny od 1927). Niezależnie od powojennych losów polskiej socjologii, jej instytucjonalny początek w tej optyce znajdował się w Poznaniu, co przez lata wzmacniało symboliczną pozycję działających tu socjologów. Warto wspomnieć także o tym, że powoływanie się na założyciela danej instytucji, niezależnie od jego dokonań, pozwala na pokazanie jej długiego trwania i sukcesu organizacyjnego.

Ukazanie Znanieckiego jako wybitnego naukowca o międzynarodowej sławie służy także podkreślaniu odrębności i ważności poznańskiego ośrodka akademickiego. Tradycje akademickie Poznania sięgają roku 1519, gdy założono tutaj Akademię Lubrańskiego - druga po Akademii Krakowskiej uczelnię wyższą w Polsce. Jednak późniejsze losy tej i innych tego typu instytucji pełne były problemów; nie sprzyjały im przede wszystkim reformy Komisji Edukacji Narodowej oraz działania władz pruskich i niemieckich w czasach zaborów ${ }^{36}$. Powołanie w 1919 r. Uniwersytetu Poznańskiego było spełnieniem wielopokoleniowych dążeń lokalnej społeczności oraz wynikiem

\footnotetext{
34 Ziółkowski (1970): 7-8.

35 Kubera (2019): 137.

36 Łukomski (2020): 109-118.
} 
wieloletnich działań wielkopolskiego środowiska naukowego. Dlatego bardzo ważne było, aby - przy ograniczonych środkach finansowych - pozyskiwać dla tej instytucji naukowców o uznanym dorobku. Znaniecki, posiadający już wtedy ugruntowaną pozycję międzynarodową (głównie dzięki swojej pracy w Stanach Zjednoczonych), może być symbolem sukcesu tego przedsięwzięcia. Jednocześnie podkreślanie różnorodności dokonań Znanieckiego sprawia, że powoływać się na niego moga przedstawiciele wielu różnych dyscyplin obecnych na Uniwersytecie im. Adama Mickiewicza, co pełni funkcję integrującą dla środowiska poprzez wskazanie podobieństw i wspólnych źródeł jego współczesnej działalności naukowej. W tym sensie postać Znanieckiego działa integrująco na lokalne środowisko akademickie, a przynajmniej jego społeczno-humanistyczną część.

W przypadku Poznania upamiętnienie Znanieckiego służy wsparciu narracji o międzynarodowym i lokalnym znaczeniu miasta. $Z$ jednej strony w uzasadnieniu słuszności nadania imienia Znanieckiego ulicy na Piątkowie przeczytać można o jego pionierskiej na świecie i w Polsce działalności (założenie instytutu, prowadzenie badań metodą autobiograficzna), z drugiej - uzasadnienie wskazuje na związki Znanieckiego z cała Wielkopolska. Warto zauważyć, że związki te - poza krótkotrwałym zamieszkiwaniem we wsi Łubowo (powiat gnieźnieński, gmina Łubowo) w latach 1924-1925 $5^{37}$ - nie były intensywne. Wskazanie na wielkopolski kontekst działalności Znanieckiego ma służyć zapewne pokazaniu Poznania jako stolicy całego regionu, co - wobec ówczesnego rozdrobnionego podziału administracyjnego kraju - mogło wymagać symbolicznego potwierdzania np. w oficjalnych uchwałach władz miejskich.

W przypadku osiedla Abisynia upamiętnienie dość jednoznacznie służy wskazaniu na wybitność zamieszkujacych tutejsze domy osób. Zwiększa prestiż i poczucie tożsamościowej wyjątkowości - szczególnie że tablica znajduje się na budynku pełniącym obecnie rolę przedszkola, a więc odwiedzanym przez rodziców dzieci mieszkających nie tylko na osiedlu, lecz także w jego najbliższych okolicach. Znaniecki nie jest jedynym znanym mieszkańcem, którego postać upamiętniają członkowie stowarzyszenia mieszkańców. Wraz z ich innymi działaniami wmurowanie tablicy pamiątkowej można interpretować jako przejaw tworzenia tożsamości dzielnicowej ${ }^{38}$ przez lokalnych liderów pamięci ${ }^{39}$.

W tym kontekście szczególnie ciekawe wydają się warszawskie komemoracje Znanieckiego. Tradycje akademickie w tym mieście są młodsze niż w Poznaniu, jednak ich historia jest bardziej jednostajna i bogatsza. Choć w obu miastach uniwersytety zostały zlikwidowane, w Warszawie przerwa była krótsza i nie dotknęła całkowicie szkolnictwa wyższego. Stąd brak charakterystycznej dla Poznania potrzeby podkreślania działalności naukowo-dydaktycznej pierwszych lat po odzyskaniu niepodległości. Co istotne, warszawski ośrodek socjologiczny powstał z inicjatywy innych osób - w sensie organizacyj-

\footnotetext{
37 Dulczewski (1984): 269.

38 Lisiecki, Kubera (2015): 135.

39 Skoczylas (2014).
} 
nym wyrasta z innych źródeł. Znaniecki miał jednak zwiąki z tym miastem: uczęszczał do warszawskiego gimnazjum; przez krótki okres był studentem Cesarskiego Uniwersytetu Warszawskiego; był także członkiem Towarzystwa Naukowego Warszawskiego ${ }^{40}$. Wobec tych okoliczności możliwych jest kilka interpretacji warszawskich upamiętnien.

Po pierwsze, moga one stanowić próbę pokazania Warszawy jako miejsca edukacji jednego z wybitnych przedstawicieli nauki. Warszawskie środowisko nauczycielskie i akademickie wpłynęło na Znanieckiego, współtworząc wybitna jednostkę. Na niekorzyść tej interpretacji działa fakt, że oficjalne uzasadnienie nazwania jego imieniem ulicy na Gocławiu nie zawiera w sobie żadnego odniesienia do warszawskiego okresu w jego życiu przy jednoczesnym wskazaniu jego związków z Poznaniem. Inna możliwa interpretacja wiąże się ze stołecznością Warszawy. Jako centrum życia politycznego i największe miasto kraju, Warszawa pełni faktyczną i symboliczną funkcję stolicy Polski. Stąd upamiętniane są w niej osoby zasłużone dla całej Polski, nawet jeśli Warszawa nie stanowiła głównego ośrodka ich działalności. Oczywiście zasada ta działa także w przypadku innych miejscowości, ogranicza się jednak tylko do bardzo znanych osób działających w wymiarze przede wszystkim politycznym lub artystycznym (np. Józef Piłsudski czy Adam Mickiewicz), spośród naukowców za osoby o takiej roli uznać można chyba tylko Mikołaja Kopernika i Marię Skłodowska-Curie. Pozostali naukowcy nie zajmuja wysokiej pozycji w kanonie polskiej pamięci społecznej ${ }^{41}$ i nie są często upamiętniani w nazwach ulic, placów itp. Komemoracja Znanieckiego jest więc sposobem na podkreślenie centralnej roli Warszawy w życiu społecznym, a więc także naukowym, całej Polski. Trzecia interpretacja wiąże się z członkostwem Znanieckiego w Towarzystwie Naukowym Warszawskim i wydaje się istotna szczególnie w analizie upamiętnienia w Pałacu Staszica. Obecnie w jego wnętrzu znajduja się upamiętnienia osób związanych z dwoma instytucjami: Towarzystwem Naukowym Warszawskim (i jego poprzednikiem, Towarzystwem Warszawskim Przyjaciół Nauk) oraz Polską Akademią Nauk. Obie te instytucje mają swoją siedzibę w tym budynku. Komemoracja Znanieckiego jest więc w tej interpretacji elementem budowania tożsamości istniejących tam instytucji, wskazania wieloletniej ich trwałości oraz wpływu na naukę. Oddziałuje integrująco na środowisko naukowe, szczególnie to związane fizycznie miejscem pracy z pałacem. Nieco łatwiejsza wydaje się interpretacja tablicy w Świątnikach. Upamiętnienie w miejscu urodzenia pełni jednoznaczną funkcję tożsamościowa dla lokalnej społeczności, przypominając wybitna jednostkę pochodzącą z tej samej wsi. Może ona wskazywać na wyjątkowość Świątnik oraz być wzorem dla młodzieży.

Warto na koniec wymienić inne upamiętnienia Znanieckiego, aby wyznaczyć możliwe dalsze kierunki analiz tej tematyki. Chodzi tu przede wszystkim o liczne książki biograficzne i metodologiczne. W tym względzie zdecydowanie największymi zasługami dla utrwalenia pamięci o Znanieckim

\footnotetext{
${ }^{40}$ Lista (2020).

41 Malicki (2012): 83.
} 
odznaczył się Zygmunt Dulczewski, którego książki pozostają głównym źródłem informacji biograficznych o Znanieckim. Napisał on sześć dzieł biograficznych, jedną monografię dotycząca metodologii Znanieckiego oraz wstępy do czterech obcojęzycznych wydań jego prac. Jest także autorem tłumaczenia dzieła Znanieckiego na język polski oraz redaktorem naukowym monografii zbiorowej inspirowanej jego dokonaniami. Andrzej Kwilecki zredagował monografię zbiorową podsumowującą konferencję w 1972 r., wydał jedną własną monografię dotycząca Znanieckiego oraz współredagował (wraz z Bohdanem Czarnockim) publikację w języku angielskim o Znanieckim. Wybór tekstów z dzienników Teodora Abla poświęconych Znanieckiemu został natomiast opublikowany dzięki staraniom Elżbiety Hałas. W samej Polsce do roku 2021 wydano ponad 20 monografii oraz kilka numerów tematycznych czasopism analizujących metodologię lub myśl społeczną Znanieckiego.

W 1994 r. wydano w Polsce znaczek pocztowy o wartości 9000 złotych z podobizną Znanieckiego i podpisem „prof. Florian Znaniecki 1882-1958”42. Zaprojektował go Andrzej Gasik. Wprowadzono go 15 lipca w Urzędzie Pocztowym Poznań 1 i pozostał w obiegu do końca 1996 r. Wydrukowano go w technice offsetowej. Pomysłodawca tej formy upamiętnienia był Zygmunt Dulczewski, a swoje starania zaczął najpewniej już w 1982 r.

W 2020 r. Fundacja Naukowa im. Floriana Znanieckiego wydała ulotkę „Florian Znaniecki w Poznaniu”, opisująca miejsca związane ze Znanieckim $\mathrm{w}$ formie miniprzewodnika turystycznego. Było to pierwsze upamiętnienie dostępne szerszemu gronu odbiorców niebędące tablica pamiątkową od czasu artykułów prasowych z 1968 r. Ulotkę wydano w języku polskim oraz angielskim.

Warto wreszcie zwrócić uwagę także na istnienie niematerialnych komemoracji Znanieckiego, które przybierają bardzo różne formy instytucjonalne: Nagroda im. Floriana Znanieckiego (przyznawana przez PAN i Towarzystwo Łączności z Polonią Zagraniczną od 1979 r., ob. przez Polskie Towarzystwo Socjologiczne), Fundacja Naukowa im. Floriana Znanieckiego (założona w 1989), Towarzystwo Naukowe im. Floriana Znanieckiego (założone w 1992), Centrum Myśli Społecznej im. Floriana Znanieckiego (istniejące w latach 2014-2018). Ich działalność i rola w animowaniu naukowego życia polskich socjologów zasługują na osobna analizę. Na University of Illinois at Urbana-Champaign istnieje nagroda: Znaniecki Publication Prize, przyznawana od 2009 r. doktorantom za wyróżniający się opublikowany tekst naukowy, oraz honorowy tytuł Florian Znaniecki Professorial Scholar dla nowo zatrudnionych naukowców z tytułem doktora, który dana osoba otrzymuje na okres 5 lat i który wiąże się $\mathrm{z}$ dostępem do celowego funduszu badawczego. Oba zostały ustanowione dzięki staraniom Tima F. Liao. Także te dwie amerykańskie formy upamiętnienia Znanieckiego zasługują na osobne omówienie.

${ }^{42}$ Zarządzenie Ministra Łączności nr 511 z 19 października 1993 r. zmieniające zarządzenie w sprawie planu emisji znaczków pocztowych na 1994 r. 1993. Monitor Polski 55: 828. 
Bielecka-Prus, J. (2009). Społeczne role socjologów w PRL. Przegląd Socjologiczny 58(2): 71-103.

Collegium Znanieckiego (2010). Życie Uniwersytecie 11(206): 6.

Dulczewski, Z. (1984). Florian Znaniecki: Życie i dzieło. Poznań.

Dulczewski, Z. (1999). Archiwum Floriana Znanieckiego. Poznań.

Dulczewski, Z. (2000). O Florianie Znanieckim. Poznań.

Jakubczak, F. (1968a). Nestor pamiętnikarstwa ludowego. Sztandar Ludu 71 (23/24.03.1968).

Jakubczak, F. (1968b). Florian Znaniecki - założyciel instytucji pamiętnikarstwa ludowego. W 10. rocznicę śmierci 15.01.1882-23.03.1958. Dziennik Ludowy 71: 23.03.1968.

Kubera, J., Skoczylas, Ł., Szerksznis, Ż. (2017). Towards a revival of Znaniecki's achievements? Florian Znaniecki's theory and methodology: their presence in citation databases and possible applications in contemporary migration studies, [w:] J. Kubera, Ł. Skoczylas (eds.), Contemporary Migrations in the Humanistic Coefficient Perspective. Fankfurt am Main: $215-249$.

Kubera, J. (2019). Not only the 'Polish Peasant'. Znaniecki's Poznań School of Sociology as a Sociological and a Research Issue. Przegląd Socjologiczny 68(4): 125-148.

Kwilecki, A. (2007). Silva rerum: ludzie - instytucje - wydarzenia. Zapiski i wspomnienia. Poznań.

Lisiecki, S., Kubera, J. (2015). O zasadności badań nad tożsamością dzielnic miast. Poszukiwanie nowych-starych tożsamości. Acta Universitatis Lodziensis. Folia Sociologica 54: 127-139.

Lista członków Towarzystwa Naukowego Warszawskiego od 1907 r. (2020). Strona internetowa Towarzystwa Naukowego Warszawskiego, <http://www.tnw.waw.pl/index.php/czlonkowie/ 96-lista-czonkow-od-1907-r> [dostęp: 7.10.2020].

Łukomski, G. (2020). Pięć wieków tradycji. Kształtowanie się poznańskiego środowiska akademickiego, [w:] L. Mrozewicz (red.), W kręgu gnieźnieńskiej humanistyki. Poznań: 109-130.

Madeyski, J. (2000). Słowo wstępne, [w:] Z. Wolska, Rzeźba. Warszawa: 8-53.

Malicki, K. (2012). Pamięć przeszłości pokolenia transformacji. Warszawa.

Napiórkowski, M. (2014). Upamiętnienie, [w:] M. Saryusz-Wolska, R. Traba (red.), Modi memorandi: Leksykon kultury pamięci. Warszawa: 509-513.

Nowak, M. (2010). Czy pokolenia socjologów? Historyczne źródła, współczesne interpretacje, [w:] B. Mateja, B. Pawłowska, F. Schmidt, M. Weres (red.), Studiować socjologię w XXI wieku. Poznań: 33-57.

Nazewnictwo ulic, placów i innych obiektów m.st. Warszawy. (2020). Strona internetowa urzędu stołecznego miasta Warszawy. <http://mapa.um.warszawa.pl/> [dostęp: 16.07.2020].

Przybylski, A. (2017). Abisynia - osiedle na poznańskim Grunwaldzie. Poznań.

Poznań: Plan miasta (1985). Państwowe Przedsiębiorstwo Wydawnictw Kartograficznych. Warszawa.

Poznań: Plan miasta (1987). Państwowe Przedsiębiorstwo Wydawnictw Kartograficznych. Warszawa.

Rapley, T. (2013). Analiza dyskursu, konwersacji I dokumentów. Tłum. A. Gąsior-Niemiec. Warszawa.

Rhoades, L.J. (1981). A History of the American Sociological Association 1905-1980. Washington DC.

Skoczylas, Ł. (2014). Pamięć społeczna miasta - jej liderzy i odbiorcy. Warszawa.

Thomas, W.I., Znaniecki, F. (1918). The Polish Peasant in Europe and America. Boston.

Tyszka, Z. (1975). Socjologia poznańska po Znanieckim, [w:] A. Kwilecki (red.), Florian Znaniecki i jego rola w socjologii. Poznań: 169-177.

Wolska, Z. (2000). Rzeźba. Warszawa.

Wójtowicz, A. (2017). Metamorfozy Pałacu Staszica. Warszawa.

Ziółkowski, M. (1970). Pięćdziesiąt lat socjologii w Poznaniu. Studia Socjologiczne 2(37): 6-27.

Ziółkowski, M. (1973). Socjologia, [w:] G. Labuda (red.), Nauka w Wielkopolsce: Przeszłość i teraźniejszość. Poznań: 327-348.

Znaniecki, F. (1931). Miasto w świadomości jego obywateli Poznań.

Znaniecki Florian Witold (1882-1958) (2020). Strona urzędu stołecznego miasta Warszawy. $<$ http://mapa.um.warszawa.pl/> [dostęp: 16.07.2020].

Znaniecki ze Świątnik. 2000. Forum Akademickie 9 <https://forumakademickie.pl/fa-archiwum/ archiwum/2000/09/index.html> [dostęp: 18.07.2020]. 


\section{COMMEMORATIONS OF FLORIAN ZNANIECKI IN PUBLIC SPACES}

\section{Sum mary}

The aim of the article is to conduct an exploratory analysis of commemorations of Florian Znaniecki in public spaces. Florian Znaniecki was one of the founders of Polish institutional sociology and one of the representatives of humanistic sociology. The text briefly presents Znaniecki's achievements, describes his commemorations in Warsaw, Poznań, and Świątniki, as well as the history of their establishment, and then analyses these commemorations from the perspective of their impact on social memory. The research was conducted using document analysis. The research identified basic justifications used in Znaniecki's commemorations. These are: his organizational activity, educational activity, international recognition, connection with a region or place, methodological achievements, role in science, scientific pioneering, and the diversity of his scientific achievements.

Keywords: Florian Znaniecki; social memory; collective memory; commemoration; history of sociology 
